\title{
Genetic diversity and characterization of arsenic-resistant endophytic bacteria isolated from Pteris vittata, an arsenic hyperaccumulator
}

Yunfu Gu+ ${ }^{*} \mathbb{D}$, Yingyan Wang ${ }^{\dagger}$, Yihao Sun ${ }^{\dagger}$, Ke Zhao, Quanju Xiang, Xiumei Yu, Xiaoping Zhang and Qiang Chen

\begin{abstract}
Background: Alleviating arsenic (As) contamination is a high-priority environmental issue. Hyperaccumulator plants may harbor endophytic bacteria able to detoxify As. Therefore, we investigated the distribution, diversity, As (III) resistance levels, and resistance-related functional genes of arsenite-resistant bacterial endophytes in Pteris vittata $\mathrm{L}$. growing in a lead-zinc mining area with different As contamination levels.

Results: A total of 116 arsenite-resistant bacteria were isolated from roots of $P$. vittata with different As concentrations. Based on the $16 \mathrm{~S}$ rRNA gene sequence analysis of representative isolates, the isolates belonged to Proteobacteria, Actinobacteria, and Firmicutes. Major genera found were Agrobacterium, Stenotrophomonas, Pseudomonas, Rhodococcus, and Bacillus. The most highly arsenite-resistant bacteria (minimum inhibitory concentration $>45 \mathrm{mM}$ ) were isolated from $P$. vittata with high As concentrations and belonged to the genera Agrobacterium and Bacillus. The strains with high As tolerance also showed high levels of indole-3-acetic acid (IAA) production and carried arsB/ACR3(2) genes. The arsB and $A C R 3(2)$ were most likely horizontally transferred among the strains.

Conclusion: The results of this study suggest that $P$. vittata plants with high As concentrations may select diverse arsenite-resistant bacteria; this diversity might, at least partly, be a result of horizontal gene transfer. These diverse endophytic bacteria are potential candidates to enhance phytoremediation techniques.
\end{abstract}

Keywords: Pteris vittata, Endophytic bacteria, Genetic diversity, Arsenite resistance, Arsenic transport genes, Horizontal gene transfer

\section{Background}

Arsenic (As) is a trace metalloid element present in various soil and water ecosystems and originated from both natural processes and human activities [1]. Chronic exposure to soil As possess potential health risks to environment and human health because of its toxicity and carcinogenicity [2]. Moreover, soil contamination with As affects the physiology, growth, and grain quality of crops. For example, the As concentrations in rice grains from Chenzhou, China, exceeded the maximum allowable value

\footnotetext{
* Correspondence: guyf@sicau.edu.cn

${ }^{\dagger}$ Equal contributors

Department of Microbiology, College of Resource Science and Technology, Sichuan Agricultural University, Chengdu 611130, China
}

of $0.5 \mathrm{mg} \mathrm{kg}^{-1}$ (dry weight) [3]. However, the efficient remediation of As-contaminated soil and water is a major environmental challenge, calling for the development of sophisticated remediation strategies.

Phytoremediation employs plants to accumulate, transfer, stabilize, and remove trace elements from polluted soils and water systems. It has received considerable attention due to its economic and environmental benefits [4]. However, there are several limiting factors affecting the effectiveness of phytoremediation, including plant growth rate, contaminant phytotoxicity, root biomass decrease, and limited uptake of contaminants [5]. In terms of suitable plant species, the arsenic hyperaccumulator plant $P$. vittata. L (Chinese brake fern) has 
potential to be used in the phytoremediation of Ascontaminated soils, since it is able to accumulate more than $1000 \mathrm{mg} \mathrm{kg}^{-1}$ of As in its fronds [6]. Plantassociated microbes could affect the efficiency of metal extraction by plants and thereby enhance phytoremediation processes $[7,8]$. They play an important role in the transformation of arsenic, including arsenite (As(III)) oxidation, arsenate $(\mathrm{As}(\mathrm{V}))$ respiration, and $\mathrm{As}(\mathrm{V})$ reduction, thus affecting the bioavailability and toxicity of As in soils [9]. However, our knowledge about endophytic microorganisms associated with $P$. vittata and their roles in As tolerance and transformation is severely limited.

Endophytic bacteria, which have great potential in enhancing phytoremediation processes $[7,10]$, can colonize internal plant parts, without any detrimental effects on the hosts [11]. Such bacteria are diverse and influenced by edaphic properties and contaminant contents of both the soil and plant tissue $[12,13]$. Some endophytes can promote plant growth by improving nutrient uptake and increasing resistance to metals, suggesting their application in phytoremediation [14]. Bacteria have developed different strategies to transform arsenic, including cytoplasmic arsenate reduction, arsenite oxidation, respiratory arsenate reduction, and arsenite methylation [15]. The reduction of arsenate, followed by the extrusion (efflux) of arsenite, is the main mechanism of arsenate tolerance in bacteria [16]. Arsenite efflux is carried out by membrane carrier proteins or pumps, such as ArsB or ArsAB complexes and Acr3p. Although the arsenite transporter genes ars $B$ and $A c r 3 p$ have been identified in various soil bacterial species [17], knowledge about these genes in endophytic bacteria is still lacking. Moreover, the relation between genotypes and arsenite resistance levels has not been addressed. Thus, studying the diversity and distribution of indigenous bacterial endophytes in $P$. vittata is crucial to improve phytoremediation strategies for As-contaminated sites.

In this context, we isolated endophytic bacteria from $P$. vittata from a $\mathrm{Pb}-\mathrm{Zn}$ mine soil for analysis of the $16 \mathrm{~S}$ rRNA gene and arsenite transporter gene (e.g. ars $B$ and $A c r 3 p$ ) diversity. The objectives of this study were to (1) evaluate the distribution and diversity of arseniteresistant endophytic bacteria in $P$. vittata with different arsenic contamination levels; and (2) investigate the arsenite transporter genes and correlate their presence to the arsenic resistance level of the bacteria. We hypothesized that the distribution and diversity of endophytic bacteria and their arsenite transporter genes are related to the As concentration in P. vittata roots.

\section{Methods}

\section{Ethics statement}

No specific permits were required for the described studies. No specific permissions were required for these locations/activities because sample collection did not involve endangered or protected species or privately owned location.

\section{Study sites and sampling strategy}

Sampling was performed in the Tangjia $\mathrm{Pb}-\mathrm{Zn}$ mine in Hanyuan, Sichuan $\left(29^{\circ} 24^{\prime} 39^{\prime \prime}\right.$ N, $102^{\circ} 39^{\prime} 24^{\prime \prime}$ E), 890 m above sea level. The area has a mean annual temperature of $18.5^{\circ} \mathrm{C}$, with a mean annual precipitation of $486 \mathrm{~mm}$ and an average annual evaporation of $1553 \mathrm{~mm}$. Based on the findings of a previous field survey, $P$. vittata is the dominant species in this area [18].

With regard to the distribution of the slag heaps, four different soils within the mining area, with different arsenic contamination levels, were selected: an ore outlet (site S2) and a tailing dam with smelting wastes and wastewater (site S3) with high As-contamination levels, and an ore charge heap (site S4) and a slag heap (site S5) with intermediate levels. A field used to cultivate summer rice and winter wheat, approximately $10 \mathrm{~km}$ from the mine area, was chosen as a non-contaminated control site (site S1). Soil and ferns samples (reproductive stage) were collected in August 2016 with the permission of the land owner. For this, three plots of $16 \mathrm{~m} \times 10 \mathrm{~m}$ were randomly established in each site; each plot was divided into four $8 \mathrm{~m} \times 5 \mathrm{~m}$ sampling subplots. Fresh roots and the corresponding rhizosphere soils from three individual $P$. vittata plants were sampled from each subplot. The samples from the subplots were pooled and homogenized to form a composite plot-level sample.

Root and soil samples were placed in polyethylene bags at $4{ }^{\circ} \mathrm{C}$ and transported to the laboratory for analyses. For metal analysis, roots were washed with distilled water and dried to constant weight at $55{ }^{\circ} \mathrm{C}$. Dried roots were ground into a fine powder and digested with $\mathrm{HNO}_{3} /$ $\mathrm{HClO}_{4}(87 / 13 v / v)$. Soil samples were air-dried at ambient room temperature $\left(25^{\circ} \mathrm{C}\right)$ and sieved through a 6-mm sieve. Then metals in the soil samples were extracted with aqua regia. Total concentrations of $\mathrm{As}, \mathrm{Pb}, \mathrm{Zn}, \mathrm{Cu}$, and $\mathrm{Cd}$ in root extractant and aqua regia were determined using an inductively coupled-plasma optical emission spectrometer (ICP-AES, IRIS Intrepid II, Thermo Electron, USA) [19]. Soil pH was determined with a potentiometry method, using a soil-to-water ratio of 1:5 [20]. Soil water content (WC) was determined after oven-drying at $105{ }^{\circ} \mathrm{C}$ for $48 \mathrm{~h}$ [20]. Soil total nitrogen (TN) and organic carbon (SOC) were analyzed via the potassium dichromate oxidation-external heating method and the alkaline hydrolysis diffusion method, respectively [20].

\section{Isolation of as-resistant endophytic bacterial strains}

The $P$. vittata root samples were washed with tap water, followed by three rinses with deionized water and 
sterilization by sequential immersion in $70 \%(\mathrm{v} / \mathrm{v})$ ethanol for $2 \mathrm{~min}$ and $1 \%$ mercuric chloride for $1 \mathrm{~min}$; subsequently, samples were rinsed three times with sterile water. Water from the last rinse was plated on LuriaBertani's (LB) agar to test whether the root surface was successfully disinfected. Surface-sterilized roots (approximately $0.5 \mathrm{~g}$ ) were ground by a mortar and pestle in $5 \mathrm{ml}$ of $\mathrm{ddH}_{2} \mathrm{O}$. Sterile quartz sand was added to the mortar to improve cell wall disruption. Serial dilutions were plated on LB medium containing $800 \mu \mathrm{M} \mathrm{NaAsO}{ }_{2}$ and incubated at $28{ }^{\circ} \mathrm{C}$ for 7 days. Single colonies were picked and restreaked several times to obtain pure isolates. Isolates were stored on LB medium at $4{ }^{\circ} \mathrm{C}$.

\section{Genomic DNA extraction, PCR amplification, and ARDRA}

Genomic DNA of the isolates was extracted from isolates grown in $5 \mathrm{~mL}$ of LB liquid medium at $28{ }^{\circ} \mathrm{C}$ with $150 \mathrm{rpm}$ for $18 \mathrm{~h}$, using the standard phenol-chloroform method described by Chang et al. [21]. The 16S rRNA gene was amplified in a T100 ${ }^{\mathrm{Tu}}$ thermal cycler (Bio-Rad, Hemel Hempstead, UK), using a pre-denaturation step at $94{ }^{\circ} \mathrm{C}$ for $4 \mathrm{~min}$, followed by 30 cycles of $50 \mathrm{~s}$ at $94{ }^{\circ}$ C, $55 \mathrm{~s}$ of annealing at $57{ }^{\circ} \mathrm{C}, 80 \mathrm{~s}$ extension at $72{ }^{\circ} \mathrm{C}$, and a final extension for $8 \mathrm{~min}$ at $72{ }^{\circ} \mathrm{C}$. The PCR mixture $(25 \mu \mathrm{L})$ contained $50 \mathrm{ng}$ of DNA template, $1.5 \mathrm{mM}$ $\mathrm{MgCl}_{2}, 2.5 \mathrm{U}$ Taq DNA polymerase (Invitrogen, USA), $1 \times$ PCR buffer, 100 pmol of the primers BSF 8/20: $5^{\prime}$ AGAGTTTGATCCTGGCTCAG-3'; BSR1541/20: 5' AAGGAGGTGATCCAGCCGCA-3' [22], and $200 \mu \mathrm{M}$ of each dNTP. The PCR products were checked by electrophoresis in a $1 \%(w / v)$ agarose gel with $0.5 \mu \mathrm{g} \mathrm{mL} \mathrm{m}^{-1}$ ethidium bromide; subsequently, obtained PCR products $(1.5 \mathrm{~kb})$ were purified with a Gel Extraction Kit (SBS Genetech, Shanghai, China).

In the amplified rDNA restriction fragment analysis (ARDRA), purified PCR products (about $5 \mu \mathrm{l}$ ) were digested at $37^{\circ} \mathrm{C}$ for $4 \mathrm{~h}$, using the restriction enzymes HhaI, HaeIII, MspI, and TaqI. Based on colony morphology and the 16S rRNA gene ARDRA pattern, representative isolates were selected for $16 \mathrm{~S}$ rRNA gene sequencing in an $\mathrm{ABI} 3730 \mathrm{XL}$ automatic sequencer at Sangon Biotech (Shanghai, China).

\section{Amplification of ars $B$ and $A C R 3(2)$ genes}

The $\operatorname{ars} B$ genes were amplified with the degenerate primers darsB1F (5'-GGTGTGGAACATC- GTCTGGA AYGCNAC-3') and darsB1R (5'-CAGGCCGTACACCACCAGRTACATNCC-3') [17]. The ACR3 (2) genes were amplified with the primers dacr5F (5'-TGAT CTGGGTCATGATCTTCCC- VATGMTGVT-3') and dacr4R (5'-CGGCCACGGCCAGYTCRAARAARTT-3') [17]. The PCR products were purified with a Gel Extraction Kit (SBS Genetech, Shanghai, China) and sequenced as described above.

\section{DNA sequencing and phylogenetic analysis}

All amplified products were sequenced using an ABI3730XL automatic sequencer at Sangon Biotech (Shanghai, China). Similar sequences were searched using BlastN for $16 \mathrm{~S}$ rRNA gene and BlastX for arsB/ $A c r 3 p$. Sequences from the isolates and reference sequences from GenBank were checked manually and edited to the same lengths, using the software package ClustalX 2.0 [23]. Phylogenetic trees were constructed by the neighbor-joining distance method, using the software package MEGA 5.0 [24]. The reliability of inferred trees was tested with 1000 bootstrap replicates.

\section{Determination of arsenite resistance and indole-3-acetic acid (IAA) and siderophore production}

The minimum inhibitory concentrations (MICs), defined as the lowest concentrations of arsenic as $\mathrm{NaAsO}_{2}$ that inhibited growth in chemically defined medium (CDM) broth, were tested in triplicate. Stock solutions of $\mathrm{NaAsO}_{2}$ were prepared in $\mathrm{ddH}_{2} \mathrm{O}$ and sterilized. Isolates were inoculated in $3 \mathrm{~mL}$ of $\mathrm{CDM}$ broth supplemented with $6,8,10,15,20,25,30,36,42$, and $48 \mathrm{mM} \mathrm{NaAsO}_{2}$ and incubated at $28{ }^{\circ} \mathrm{C}$ for 4 days. Low salt phosphate (LSP) agar plates without $\mathrm{NaAsO}_{2}$ were used as controls. The IAA production was measured as described by Sheng et al. [25], while production of siderophores was evaluated using the chrome azurol-S (CAS) analytical method [26, 27].

\section{Nucleotide sequence accession numbers}

The sequences obtained in this study were deposited in the NCBI GenBank database under accession numbers MF185755-MF185785 for 16S rRNA genes, MF185786MF185798 for arsB, and MF185799-MF185803 for ACR3(2).

\section{Statistical analysis}

Analysis of variance and the Student-Newman-Keuls (SNK) test $(P<0.05)$ were used to compare treatment means. All analyses were performed using SPSS 13.0 for Windows (SPSS Inc., Chicago, USA).

\section{Results}

Soil physicochemical parameters and metal contents

All soils in the sampling sites were alkaline. However, the $\mathrm{pH}$ in the mine area was significantly higher than that in the non-contaminated control site S1 (Table 1). Soil WC in the control site was higher than in the mining area. The highest TN and SOC levels were detected at $\mathrm{S} 1$ and the lowest at S5. The highest concentrations of $\mathrm{Cu}, \mathrm{Cd}, \mathrm{Zn}, \mathrm{Pb}$, and As were detected at S3 (Table 1). 
Table 1 The physico-chemical properties and heavy metal contents of the soils

\begin{tabular}{llllllllll}
\hline Sampling site & $\mathrm{pH}$ & $\mathrm{WC}(\%)$ & $\mathrm{TN}\left(\mathrm{g} \mathrm{kg}^{-1}\right)$ & $\mathrm{SOC}(\%)$ & $\mathrm{Cu}\left(\mathrm{mg} \mathrm{kg}^{-1}\right)$ & $\mathrm{Cd}\left(\mathrm{mg} \mathrm{kg}^{-1}\right)$ & $\mathrm{Zn}\left(\mathrm{mg} \mathrm{kg}^{-1}\right)$ & $\mathrm{Pb}\left(\mathrm{mg} \mathrm{kg}^{-1}\right)$ & $\mathrm{As}\left(\mathrm{mg} \mathrm{kg}^{-1}\right)$ \\
\hline S1 & $7.55 \pm 0.07 \mathrm{c}$ & $6.26 \pm 0.43 \mathrm{a}$ & $0.25 \pm 0.03 \mathrm{a}$ & $4.76 \pm 0.26 \mathrm{a}$ & $0.12 \pm 0.01 \mathrm{c}$ & $0.07 \pm 0.01 \mathrm{e}$ & $53.4 \pm 3.35 \mathrm{~d}$ & $15.6 \pm 1.12 \mathrm{e}$ & $5.36 \pm 0.87 \mathrm{c}$ \\
S2 & $7.78 \pm 0.02 \mathrm{a}$ & $2.32 \pm 0.62 \mathrm{c}$ & $0.12 \pm 0.02 \mathrm{~b}$ & $4.37 \pm 0.08 \mathrm{a}$ & $0.88 \pm 0.05 \mathrm{~b}$ & $5.15 \pm 0.52 \mathrm{~b}$ & $245.7 \pm 2.97 \mathrm{c}$ & $411.3 \pm 10.3 \mathrm{~b}$ & $21.3 \pm 1.23 \mathrm{a}$ \\
S3 & $7.71 \pm 0.04 \mathrm{~b}$ & $2.88 \pm 0.28 \mathrm{c}$ & $0.10 \pm 0.02 \mathrm{~b}$ & $4.23 \pm 0.55 \mathrm{a}$ & $3.40 \pm 0.35 \mathrm{a}$ & $7.99 \pm 0.08 \mathrm{a}$ & $790.4 \pm 7.22 \mathrm{a}$ & $882.5 \pm 78.5 \mathrm{a}$ & $24.5 \pm 1.13 \mathrm{a}$ \\
S4 & $7.63 \pm 0.03 \mathrm{ab}$ & $4.73 \pm 0.47 \mathrm{~b}$ & $0.11 \pm 0.01 \mathrm{~b}$ & $4.10 \pm 0.51 \mathrm{a}$ & $0.53 \pm 0.15 \mathrm{~b}$ & $1.12 \pm 0.57 \mathrm{~d}$ & $367.9 \pm 6.52 \mathrm{~b}$ & $258.2 \pm 33.0 \mathrm{c}$ & $10.8 \pm 2.01 \mathrm{~b}$ \\
S5 & $7.78 \pm 0.02 \mathrm{a}$ & $4.15 \pm 0.55 \mathrm{~b}$ & $0.09 \pm 0.01 \mathrm{~b}$ & $3.65 \pm 0.06 \mathrm{a}$ & $0.72 \pm 0.16 \mathrm{~b}$ & $2.34 \pm 0.18 \mathrm{c}$ & $333.2 \pm 45.3 \mathrm{~b}$ & $177.6 \pm 15.3 \mathrm{~d}$ & $12.3 \pm 0.85 \mathrm{~b}$ \\
\hline
\end{tabular}

Data are mean \pm SE $(n=3)$; different letters in the same column indicate statistically significant differences (SNK test, $P<0.05)$. WC soil gravimetric water content; $T N$ total nitrogen, SOC soil organic carbon

\section{Metal concentrations in $P$. vittata roots}

Concentrations of $\mathrm{Cu}, \mathrm{Cd}, \mathrm{Zn}, \mathrm{Pb}$, and $\mathrm{As}$ in the $P$. vittata roots varied significantly $(P<0.05$; Table 2$)$. Concentrations of $\mathrm{Cu}, \mathrm{Cd}, \mathrm{Pb}$, and $\mathrm{As}$ were highest at $\mathrm{S} 2$, while the Zn level was highest at S3. Compared with the control site, the $\mathrm{Cu}, \mathrm{Cd}, \mathrm{Zn}, \mathrm{Pb}$, and As concentrations were 2.7 to $6.2(\mathrm{~S} 2), 2.44$ to $6.59(\mathrm{~S} 3), 0.77$ to $6.27(\mathrm{~S} 4)$, and 2.04 to 6.34 (S5) times higher, respectively.

\section{Diversity and phylogeny of endophytic bacteria}

A total of 116 As-resistant endophytic isolates were obtained. To estimate the diversity, the $16 \mathrm{~S}$ rRNA genes of the isolates were analyzed by ARDRA, resulting in 16 different ARDRA patterns (Table 3). The 46 representative isolates, selected based on colony morphology and ARDRA, carried 16S rRNA genes 99-100\% similar with the reference sequences in GenBank. The representative isolates belonged to five genera in four families: Alphaproteobacteria (17 isolates, one genus), Gammaproteobacteria (eight isolates, two genera), Actinobacteria (three isolates, one genus), and Firmicutes (18 isolates, one genus) (Fig. 1). Fifteen of the isolates were obtained from the slag heap site (S5), 12 from the tailing dam site (S3), seven from the ore charge heap site (S4), nine from the ore outlet site (S2), and three from the control site (S1) (Fig. 1). Most of the isolates from the slag heap site belonged to the genus Agrobacterium. The majority of the isolates from the tailing dam site, the ore charge heap site, and the ore outlet site belonged to the genus Bacillus, while the isolates from the control site belonged to the genera Rhodococcus and Agrobacterium.

\section{Arsenite resistance levels and plant growth-promoting properties of the isolates}

In the minimum inhibitory concentration (MIC) test for arsenite, all strains grew in $15 \mathrm{mM}, 36$ in $36 \mathrm{mM}, 19$ in $42 \mathrm{mM}$, and 5 in $48 \mathrm{mM} \mathrm{NaAsO}_{2}$ (Fig. 1). All 17 Agrobacterium tumefaciens isolates showed high MICs $(\geq$ $30 \mathrm{mM}$ ), while the Rhodococcus sp. isolates showed low MICs ( $\geq 15 \mathrm{mM})$. Among the Pseudomonas isolates, the isolates containing ars $B$ showed higher MICs than those without arsB. The average MIC of the 10 Acr3(2)-carrying isolates $(40.9 \pm 4.5 \mathrm{mM})$ was higher than that of the five $\operatorname{ars} B$-carrying isolates $(25.8 \pm 2.3 \mathrm{mM})$. Five of the 19 highly arsenite-resistant isolates ( $\mathrm{MIC}>42 \mathrm{mM}$ ) were obtained from $P$. vittata roots with high arsenic levels (Fig. 1, Table 2). Isolates from the control site showed lower average MIC than the other isolates (Fig. 1).

In total, 28 out of the 46 isolates produced both IAA and siderophores (Table 3). The majority of the isolates produced 17.7-103.9 $\mu \mathrm{g} \mathrm{ml}^{-1}$ IAA. Isolates L8 (Rhizobium sp.) , L11 (Rhodococcus equi), L31 (Agrobacterium tumefaciens), and X10 (Bacillus megaterium) produced over $90 \mu \mathrm{g} \mathrm{ml}^{-1}$ of IAA. Two-thirds of the sequenced endophytes produced siderophores. Isolates L8 (Rhizobium sp.), K5 (Bacillus subtilis), and X4 (Bacillus sp.) produced more siderophores than the other isolates.

\section{Horizontal transfer of the arsenite transporter genes ars $B$ and $\operatorname{Acr} 3(2)$}

A total of 16 arsenite transporter genes, including five ars $B$ genes and $11 A C R 3(2)$ genes, were successfully amplified (Fig. 2). In the sequence analyses with the BlastX algorithm, the $\operatorname{ars} B$ and $A c r 3(2)$ formed separate clusters (Fig. 2). The $\operatorname{ars} B$ and $A c r 3(2)$ sequences of the

Table 2 Heavy metals concentration in the P. vittata roots from different sampling sites

\begin{tabular}{llllll}
\hline Sampling site & $\mathrm{Cu}\left(\mathrm{mg} \mathrm{kg}^{-1}\right)$ & $\mathrm{Cd}\left(\mathrm{mg} \mathrm{kg}^{-1}\right)$ & $\mathrm{Zn}\left(\mathrm{mg} \mathrm{kg}^{-1}\right)$ & $\mathrm{Pb}\left(\mathrm{mg} \mathrm{kg}^{-1}\right)$ & $\mathrm{As}\left(\mathrm{mg} \mathrm{kg}^{-1}\right)$ \\
\hline S1 & $11.1 \pm 2.03 \mathrm{c}$ & $8.02 \pm 1.03 \mathrm{c}$ & $157.1 \pm 35.2 \mathrm{~b}$ & $93.3 \pm 6.03 \mathrm{~d}$ & $31.3 \pm 10.2 \mathrm{c}$ \\
S2 & $65.1 \pm 5.12 \mathrm{a}$ & $37.1 \pm 3.12 \mathrm{a}$ & $974.7 \pm 65.5 \mathrm{a}$ & $587.1 \pm 22.1 \mathrm{a}$ & $308.7 \pm 12.3 \mathrm{a}$ \\
S3 & $57.7 \pm 4.22 \mathrm{a}$ & $31.7 \pm 6.12 \mathrm{ab}$ & $1035.4 \pm 34.3 \mathrm{a}$ & $499.3 \pm 23.1 \mathrm{~b}$ & $241.6 \pm 23.5 \mathrm{a}$ \\
S4 & $33.2 \pm 7.01 \mathrm{~b}$ & $19.5 \pm 5.05 \mathrm{bc}$ & $984.6 \pm 83.1 \mathrm{a}$ & $162.8 \pm 36.2 \mathrm{~d}$ & $102.2 \pm 10.4 \mathrm{~b}$ \\
S5 & $42.4 \pm 4.21 \mathrm{~b}$ & $24.4 \pm 3.22 \mathrm{ab}$ & $995.1 \pm 62.6 \mathrm{a}$ & $344.6 \pm 24.5 \mathrm{c}$ & $125.2 \pm 30.7 \mathrm{~b}$ \\
\hline
\end{tabular}

Data are mean \pm SE $(n=3)$; different letters in the same column indicate statistically significant differences $($ SNK test, $P<0.05)$ 
Table 3 Plant growth promoting characteristics of endophytic bacterial isolates from P. vittata. L.

\begin{tabular}{|c|c|c|c|c|}
\hline Isolate (closest relative sequence) & $\%$ identity & ARDRA type & IAA $\left(\mu \mathrm{g} \mathrm{ml}^{-1}\right)^{a}$ & Siderophore $^{b}$ \\
\hline L9 (Agrobacterium tumefaciens) & 99 & I & $46.6 \pm 4.36$ & - \\
\hline L17 (Agrobacterium tumefaciens) & 99 & 1 & $95.0 \pm 4.88$ & - \\
\hline L25 (Agrobacterium tumefaciens) & 99 & । & $42.5 \pm 9.42$ & + \\
\hline L31 (Agrobacterium tumefaciens) & 99 & । & $92.3 \pm 8.66$ & + \\
\hline W21 (Agrobacterium tumefaciens) & 99 & I & $32.8 \pm 2.58$ & + \\
\hline X13 (Agrobacterium rhizogenes) & 99 & $\|$ & - & ++ \\
\hline C6 (Agrobacterium rhizogenes) & 99 & $\|$ & $81.2 \pm 4.77$ & ++ \\
\hline Y2 (Agrobacterium rhizogenes) & 99 & $\|$ & $41.4 \pm 3.33$ & - \\
\hline K4 (Agrobacterium sp.) & 99 & III & $44.4 \pm 6.52$ & +++ \\
\hline K16 (Agrobacterium sp.) & 99 & III & $44.2 \pm 5.51$ & + \\
\hline X3 (Agrobacterium sp.) & 99 & III & $44.5 \pm 7.88$ & + \\
\hline L24 (Agrobacterium sp.) & 99 & III & $46.0 \pm 2.22$ & - \\
\hline W24 (Agrobacterium sp.) & 99 & III & - & - \\
\hline L19 (Agrobacterium sp.) & 99 & III & $47.6 \pm 5.54$ & + \\
\hline L4 (Rhizobium sp.) & 99 & IV & $34.8 \pm 3.11$ & + \\
\hline L5 (Rhizobium sp.) & 99 & IV & $60.9 \pm 9.66$ & +++ \\
\hline L8 (Rhizobium sp.) & 99 & IV & $103.9 \pm 11.2$ & ++++ \\
\hline W1 (Stenotrophomonas rhizophila) & 99 & V & $47.8 \pm 4.75$ & ++ \\
\hline W22 (Stenotrophomonas sp.) & 99 & $\mathrm{Vl}$ & $20.4 \pm 3.36$ & - \\
\hline L20 (Pseudomonas sp.) & 100 & VII & $34.4 \pm 2.28$ & - \\
\hline X8 (Pseudomonas sp.) & 100 & VII & $120.3 \pm 9.61$ & + \\
\hline L6 (Pseudomonas oryzihabitans) & 99 & VIII & $45.9 \pm 3.25$ & + \\
\hline L1 (Pseudomonas oryzihabitans) & 99 & VIII & $32.4 \pm 4.44$ & ++ \\
\hline W28 (Pseudomonas putida) & 99 & IX & $38.0 \pm 4.25$ & ++ \\
\hline L3 (Pseudomonas putida) & 99 & IX & $55.1 \pm 4.01$ & ++ \\
\hline C1 (Rhodococcus sp.) & 99 & $x$ & $29.5 \pm 3.15$ & ++ \\
\hline C3 (Rhodococcus sp.) & 99 & $x$ & $65.6 \pm 5.55$ & - \\
\hline L11 (Rhodococcus equi) & 99 & $X I$ & $98.8 \pm 8.16$ & +++ \\
\hline K17 (Bacillus indicus) & 99 & $X \|$ & - & + \\
\hline W12 (Bacillus cereus) & 99 & $X I I I$ & $49.2 \pm 2.17$ & + \\
\hline X2 (Bacillus muralis) & 99 & XIV & $22.9 \pm 5.43$ & - \\
\hline K5 (Bacillus subtilis) & 99 & $X V$ & $31.7 \pm 4.22$ & ++++ \\
\hline W9 (Bacillus megaterium) & 99 & $X V$ & $34.6 \pm 1.78$ & ++ \\
\hline W23 (Bacillus megaterium) & 99 & $X V$ & - & + \\
\hline X10 (Bacillus megaterium) & 99 & $X V$ & $99.6 \pm 12.7$ & +++ \\
\hline K2 (Bacillus sp.) & 99 & $\mathrm{XVI}$ & $53.1 \pm 4.33$ & ++ \\
\hline K3 (Bacillus sp.) & 99 & $\mathrm{XVl}$ & $43.6 \pm 3.16$ & - \\
\hline K12 (Bacillus sp.) & 100 & $\mathrm{XVl}$ & - & - \\
\hline K6 (Bacillus sp.) & 100 & $X \mathrm{VI}$ & $81.4 \pm 2.44$ & ++ \\
\hline W8 (Bacillus sp.) & 99 & $\mathrm{XVl}$ & $56.0 \pm 2.08$ & +++ \\
\hline W10 (Bacillus sp.) & 99 & $\mathrm{XVI}$ & $54.6 \pm 7.03$ & +++ \\
\hline W11 (Bacillus sp.) & 99 & $\mathrm{XVI}$ & - & - \\
\hline X4 (Bacillus sp.) & 99 & $\mathrm{XVI}$ & $39.0 \pm 4.21$ & ++++ \\
\hline X11 (Bacillus sp.) & 99 & $\mathrm{XVI}$ & $17.7 \pm 3.22$ & - \\
\hline
\end{tabular}


Table 3 Plant growth promoting characteristics of endophytic bacterial isolates from P. vittata. L. (Continued)

\begin{tabular}{lllll}
\hline Isolate (closest relative sequence) & \% identity & ARDRA type & IAA $\left(\mu \mathrm{ml}^{-1}\right)^{\mathrm{a}}$ & Siderophore $^{\mathrm{b}}$ \\
\hline K9 (Bacillus sp.) & 99 & $\mathrm{XVI}$ & $14.9 \pm 0.31$ & ++ \\
W3 (Bacillus sp.) & 99 & $\mathrm{XVI}$ & $15.2 \pm 0.90$ & + \\
\hline
\end{tabular}

${ }^{\mathrm{a}}$ IAA production: $-=$ not detectable; ${ }^{\mathrm{b}}$ Siderophore production: + , little; ++ , low; +++ , moderate; ++++ , high

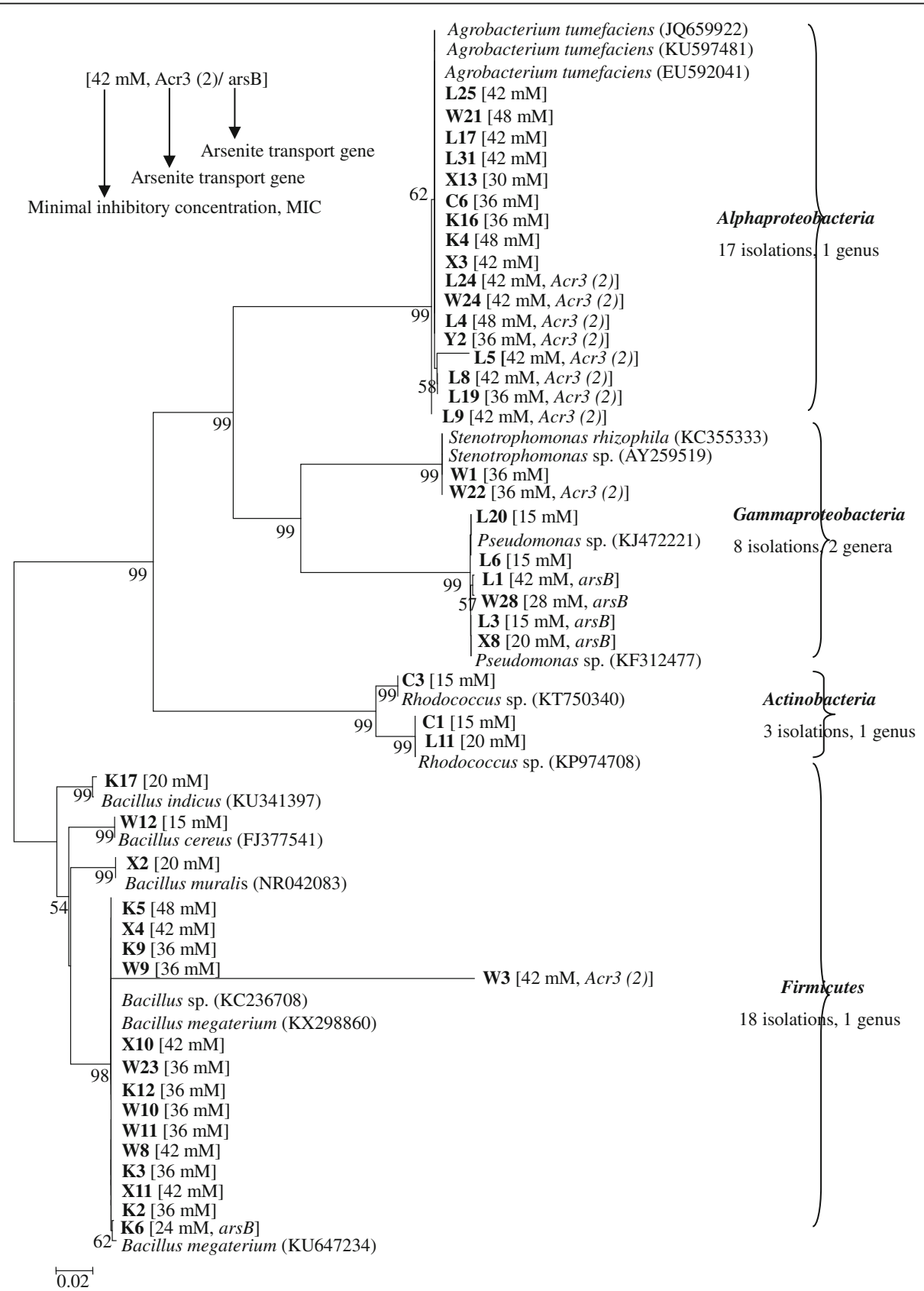

Fig. 1 Relationships between the representative isolates and the reference strains based on 16S rRNA gene ( 1500 bp) phylogenetic analysis. Minimum inhibitory concentration (MIC) for arsenite and the presence of arsenite-resistance genes ArsB/ Acr3(2) are indicated in squared brackets. Sequences from this study are in bold type. Bootstrap values over $50 \%$ are shown on the branching points. The scale bar indicates $2 \%$ nucleotide sequence substitution. Isolates with capital $L$ were isolated from the $P$. vittata roots collected from site $S 5$, with $X$ from site S4, with W from site S3, with $\mathrm{K}$ from site S2, and with C from site S1 


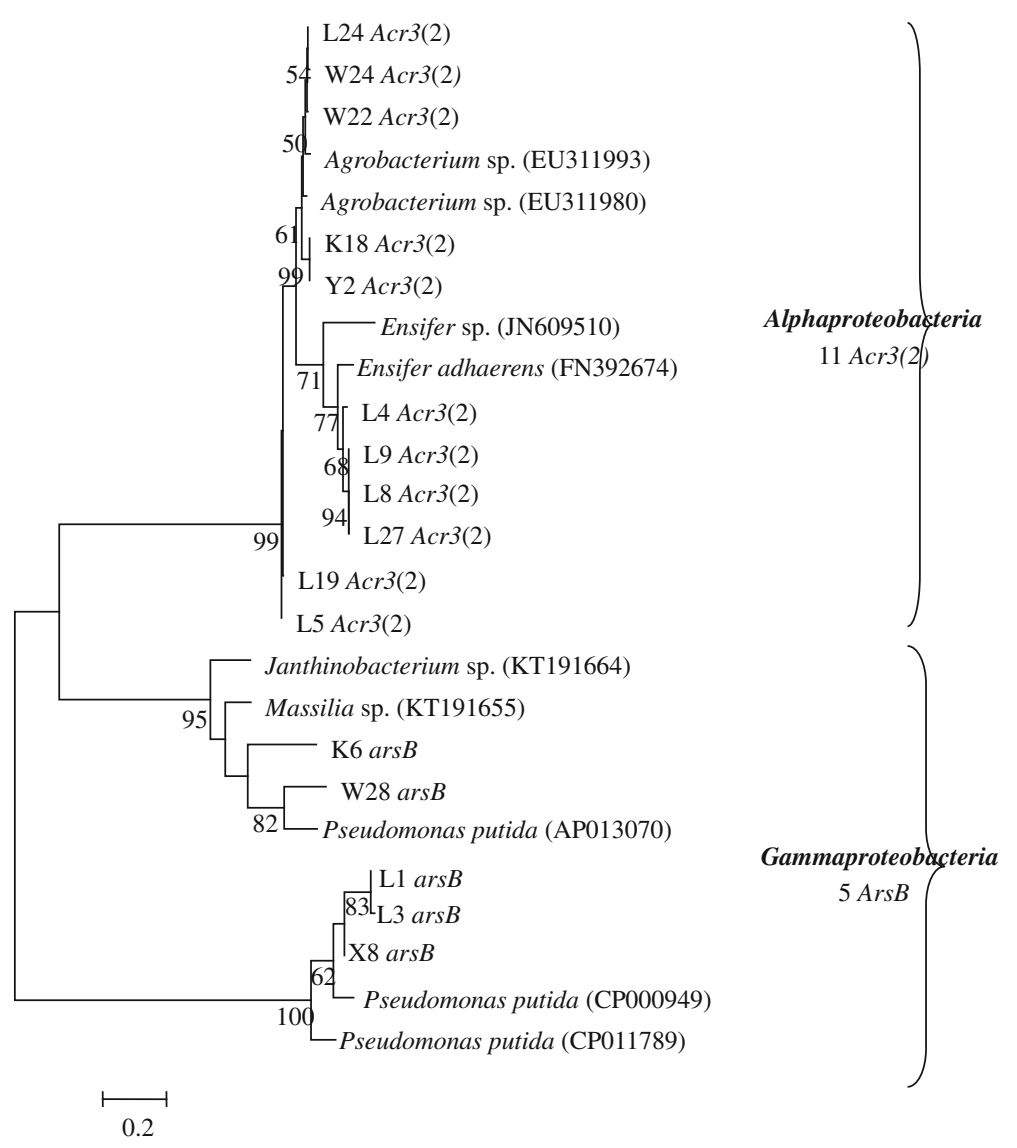

Fig. 2 Relationships between the representative isolates and the reference strains based on arsenite transporters $\operatorname{Ars} B$ and $\operatorname{Acr} 3(2)$

isolates were similar to those from Gammaproteobacteria and Alphaproteobacteria, respectively. The Acr3(2) sequences were divided into separate subgroups, similar to either Acr3(2) from Agrobacterium sp. or from Ensifer sp. Agrobacterium sp. L5, L8, L9, and L19 carried Acr3(2) similar to those of Ensifer sp. (Fig. 3). Gammaproteobacterial Stenotrophomonas sp. W22 carried Alphaproteobacteria type Acr3(2) (Fig. 3). The Bacillus sp. K6 carried arsB similar to those of the Gammaproteobacteria clade (Fig. 3). All of these, possibly horizontally transferred $A C R 3(2)$ and arsB genes, were obtained from isolates from the highly As-contaminated mining area.

\section{Discussion}

Plants that accumulate As can provide a specific environment for bacterial endophytes to adapt to high As concentrations [28]. In this work, we isolated and characterized bacterial endophytes from the roots of $P$. vittata, an arsenic hyperaccumulator growing in the $\mathrm{Pb}-\mathrm{Zn}$ mine tailings in Southwest China [18].

In our study, we isolated 116 As-resistant bacterial endophytes. Despite the small number of isolates, the Asresistant bacterial endophyte community was diverse.
The representative isolates were affiliated with Pseudomonas, Stenotrophomonas, Rhodococcus, Agrobacterium, and Bacillus. Of these, Agrobacterium, Bacillus, and Pseudomonas species have previously been reported as metal-resistant endophytes in other As-contaminated sites [29-31]. Arsenite-resistant Stenotrophomonas strains have been isolated from As-contaminated soil and water [32], but, to our knowledge, endophytic arsenite-resistant Stenotrophomonas and Rhodococcus have not been isolated earlier. Most of the representative isolates belonged to Agrobacterium (phylum Proteobacteria) and Bacillus (phylum Firmicutes). Similarly, Niresistant bacterial endophytes from Alyssum bertolonii belonged mainly to Firmicutes and Actinobacteria [33]. Moreover, 14 endophytes isolated from Sedum alfredii belonged mainly to Proteobacteria (57\%) and Firmicutes (43\%) [34]. Taken together, these results suggest that the predominant bacterial endophytes in heavy metalaccumulating plants belong to Firmicutes, Proteobacteria, and Actinobacteria [35]. These highly adapted groups may accelerate the degradation of complex soil compounds by producing extracellular enzymes, and thus stimulate the growth of other bacteria in Ascontaminated rhizosphere soil [36]. 


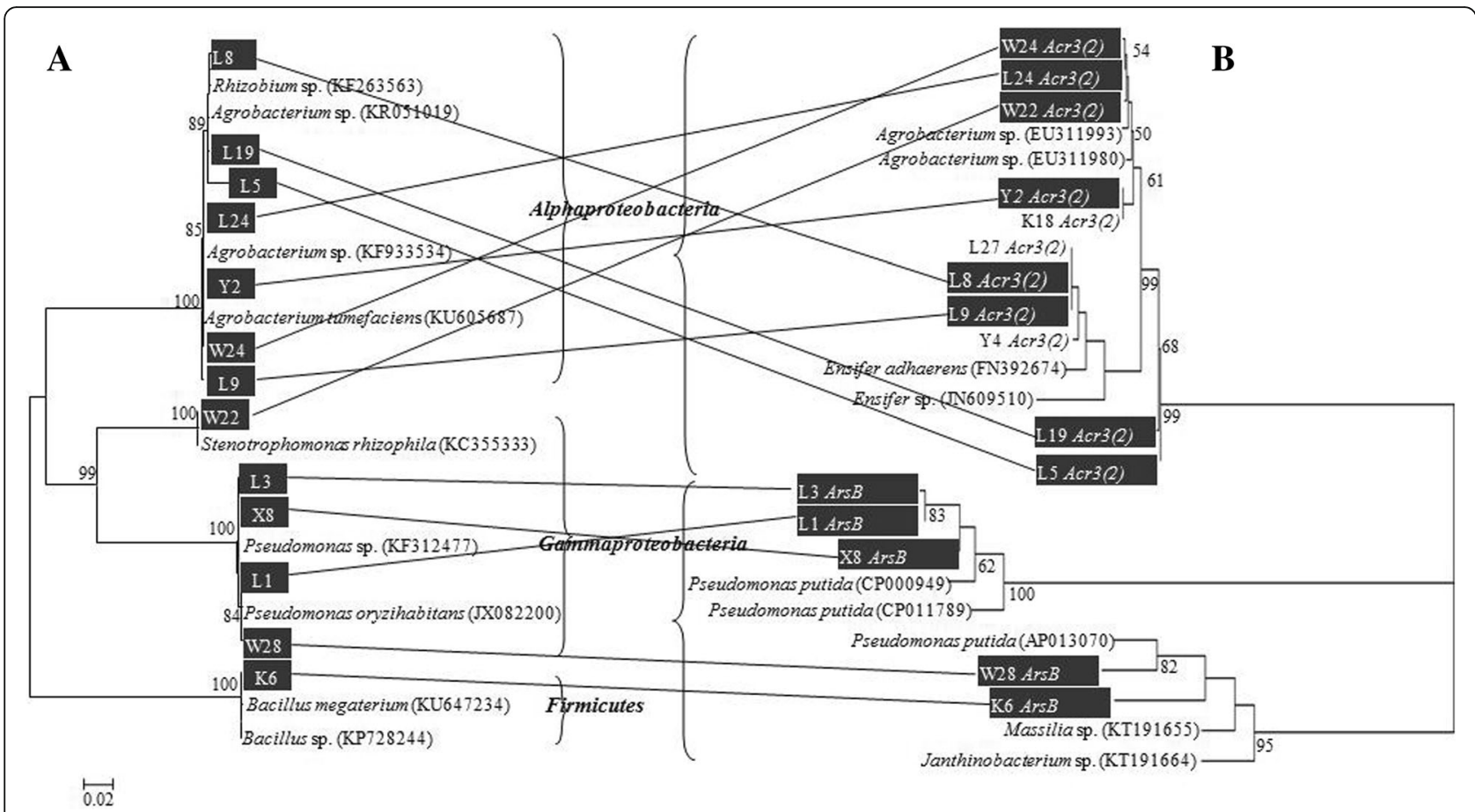

Fig. 3 Comparison of 165 rRNA gene (A) and $\operatorname{arsB/ACR3(2)~(B)~phylogenies.~The~sequences~are~subsets~from~Figs.~} 1$ and 2

Endophytic bacteria can increase the growth and development of plants growing in contaminated sites and their metal resistance by producing the phytohormone IAA and siderophores [37-39]. Siderophores are organic molecules with a high affinity for $\mathrm{Fe}(\mathrm{III})$ ions and form complexes with other metals, thus participating in nutrient mobilization and metal availability to plants [40, 41]. Bacterial siderophore production may be stimulated by heavy metals and can alleviate the toxicity of heavymetals to plants by increasing the supply of iron [41]. Arsenic-resistant strains isolated from $P$. vittata have been reported to produce siderophores [39]. Most of the isolates in our study produced IAA or siderophores, indicating that the endophytes may help their host plant to colonize As-contaminated sites [38].

In our study, $P$. vittata roots from sites S2 and S3 (with high As-concentrations) hosted a higher diversity of arsenite-resistant bacteria. In addition, the resistance levels of the isolates were also higher than those among isolates from sites with intermediate and low As concentrations. The 19 strains with arsenite MICs over $40 \mathrm{mM}$ were all isolated from $P$. vittata growing in the $\mathrm{Pb}-\mathrm{Zn}$ mining area. Previous studies have proposed that high As-contamination levels are likely to exert a strong selective pressure, thereby decreasing microbial diversity $[17,42]$. However, in our study, P. vittata was widely distributed in the $\mathrm{Pb}-\mathrm{Zn}$ mine area [18], which may result in the evolution of more bacterial species that are well adapted to highly arsenic-contaminated $P$. vittata.
Moreover, Huang et al. [43] reported that in a long-term field site (1951-present), arsenite-resistant endophytic microbial communities of $P$. vittata had had sufficient time to adapt to metal and/or metalloid stress. Zhu et al. [35] found that the diversity of As-resistant endophytes in soil with high arsenic levels was higher than that in less contaminated soil. These results suggest that endophytic bacteria have adapted to high arsenic stress levels and maintained their diversity in P. vittata after longterm exposure to high As-levels [44].

Exploring the relations among the degree of arsenite resistance, the distribution and diversity of the arsenite transporter gene families of the bacterial endophytes is a key goal of microbial ecology. The ACR3(2) genotypes were previously reported to be predominant over ars $B$ in bacterial strains isolated from As contaminated soil [17], which was similar to findings in our study. To cope with arsenic toxicity, multiple sets of arsenic resistance genes and operons were developed in the genome of nearly every bacterial species sequenced to date. For example, the full genome sequence of strain Brevibacterium linens AE038-8 contained three ars operons (arsC, $A C R 3$ and $\operatorname{arsR}$ ) and two copies of the $\operatorname{ars} O$ gene [45], Thiomonas sp. possessed two operons (aio and ars system) [46], while Rhodopseudomonas palustris CGA009 carried three sets of arsenic resistance determinants (ars1, ars2, and ars3) on the chromosome [47]. Previous study has reported that soil bacteria could acquire multiple resistance determinants via chromosomal 
duplication or horizontal gene transfer, allowing them to cope with long-term arsenic toxicity [44]. Surprisingly, in our study, none of the isolates carried both types of arsenite transporter genes, even though both these genes are commonly found on the same operon. The $A C R 3$ may have a higher affinity to arsenite and a higher rate of arsenite transport than ars $B$, which makes it more effective [44]. Accordingly, compared to the ars $B$ genecontaining strains, strains having $A C R 3(2)$ mostly showed higher arsenite resistance in our study.

Horizontal gene transfer (HGT) plays an important role in allowing a microbial community to rapidly adapt to a new environmental stress like heavy metal contamination, and thus could play an important role in the adaptation of the endogenous endophytic community [39]. In our present study, $A C R 3(2)$ appeared to be more easily transferred than $\operatorname{ars} B$, and the transfer would be possibly stimulated by the exponential growth of environmental pollution as proposed in a previous study [48]. Cai et al. [44] have reported that arsenite transporter genes were transferred between Aeromonas, Stenotrophomonas, and Comamonas in highly As-contaminated soils. Similarly, the phylogenetic discrepancies between 16S rRNA genes and $A C R 3(2) / \operatorname{ars} B$ indicate that $A C R 3(2)$ might have been horizontally transferred, especially in the isolates from $P$. vittata roots containing high As-levels. The HGT process may have occurred under the high arsenic pressure and resulted in increased functional and species diversity [49, 50], which may have practical applications in equipping the natural endophyte populations capable of resisting As and does not require long-term establishment of the inoculant strain.

\section{Conclusions}

We investigated the distribution and diversity of arsenite-resistant endophytic bacteria in $P$. vittata roots, collected from five soils with different levels of Ascontamination, and studied the arsenite resistance and arsenic transport genes of the isolates. Proteobacteria, Actinobacteria, and Firmicutes were the predominant taxa. The distribution and diversity of cultivable endophytes were affected by the arsenic concentration in $P$. vittata. A high number of the isolates were resistant to high concentrations of As and multiple heavy metals and showed plant growth-promoting characteristics. Horizontal gene transfer of $A C R 3(2)$ and $\operatorname{ars} B$ was detected in some of the isolates from $P$. vittata roots with high As concentrations. Overall, this study provides valuable information about endophytic bacterial species in relation with As transport and As-resistance genes. Our results contribute to the knowledge on the diversity and distribution of As-resistant endophytic bacteria that may be applied in the phytoremediation of Ascontaminated sites.

\section{Abbreviations}

ARDRA: Amplified rDNA restriction fragment analysis; As: Arsenic;

CAS: Chrome azurol-S; Cd: Cadmium; CDM: Chemically defined medium; Cu: Copper; DNA: Deoxyribonucleic acid; IAA: Indole-3-acetic acid; LB: LuriaBertani; MICs: Minimum inhibitory concentrations; NCBI: National center for biotechnology information; Pb: Lead; PCR: Polymerase chain reaction; pH: Post hatch; RNA: Ribosomal ribonucleic acid; SLP: Salt low phosphate; SOC: Soil organic carbon; TN: total nitrogen; WC: Water content; Zn: Zinc

\section{Acknowledgements}

The authors would like to thank Menglin Chen, Dingjian Pan, Qiaoling Lu, and Jingpeng Luo for the excellent technical support.

\section{Funding}

This work was supported by the Natural Science Foundation of China (grant number 41201256). Besides financing the funding bodies played no role in study design, collection of data, or manuscript preparation.

\section{Availability of data and materials}

Sequences obtained in this study were deposited in the NCBI GenBank database with accession numbers MF185755-MF185785 for 165 rRNA genes, MF185786-MF185798 for arsB, and MF185799-MF185803 for ACR3(2).

\section{Authors' contributions}

YFG designed the experiments and wrote the manuscript. YHS conducted the experiment. YYW analyzed the basic soil and plant physicochemical data. XMY constructed the phylogentic tree. KZ and QJX participated in the initial draft and the revision of the manuscript. XPZ coordinated the study, designed portions of the experiments. QC revised the final version of the manuscript. All authors read and approved the final manuscript.

Ethics approval and consent to participate

Not applicable.

\section{Competing interests}

The authors declare that they have no competing interests.

\section{Publisher's Note}

Springer Nature remains neutral with regard to jurisdictional claims in published maps and institutional affiliations.

Received: 31 October 2017 Accepted: 30 April 2018

Published online: 08 May 2018

\section{References}

1. Abernathy CO, Thomas DJ, Calderon RL. Health effects and risk assessment of arsenic. J Nutr. 2003;133:1536-8.

2. Zhao FJ, McGrath SP, Meharg AA. Arsenic as a food chain contaminant: mechanisms of plant uptake and metabolism and mitigation strategies. Annu Rev Plant Biol. 2010;61:535-9.

3. LiaoXY CTB, Xie H, Liu YR. Soil as contamination and its risk assessment in areas near the industrial districts of Chenzhou City, southern China. Environ Int. 2005;31:791-8

4. Gomes MP, Carvalho M, Carvalho GS, Marques TCLLSM, Garcia OS, Guilherme LRG, Soares AM. Phosphorus improves arsenic phytoremediation by Anadenanthera peregrina by alleviating induced oxidative stress. Int J Phytorem. 2013;15:633-6.

5. Shin MN, Shim J, You Y, Myung H, Bang KS, Cho M, Kamala-Kannan S, Oh BT. Characterization of lead resistant endophytic bacillus sp. MN3-4 and its potential for promoting lead accumulation in metal hyperaccumulator Alnus firma. J Hazard Mater. 2012;199:314-20.

6. Slonecker T, Haack B, Price S. Spectroscopic analysis of arsenic uptake in Pteris Ferns. Rem Sens. 2009:1:644-5.

7. Ma LQ, Komar KM, Tu C, Zhang WH, Cai Y, Kennelley ED. A fern that hyperaccumulates arsenic. Nature. 2001:409:579.

8. Weyens N, van der Lelie D, Taghavi S, Vangronsveld J. Phytoremediation: plant-endophyte partnerships take the challenge. Curr Opin Chem Biol. 2009;20:248-4.

9. Oremland RS, Stolz JF. Arsenic, microbes and contaminated aquifers. Trends Microbiol. 2005;13:45-9. 
10. Ryan RP, Germaine K, Franks A, Ryan DJ, Dowling DN. Bacterial endophytes: recent developments and applications. FEMS Microbiol Lett. 2008;278:1-9.

11. Khan Z, Doty SL. Characterization of bacterial endophytes of sweet potato plants. Plant Soil. 2009;322:197-7.

12. Ulrich K, Ulrich A, Ewald D. Diversity of endophytic bacterial communities in poplar grown under field conditions. FEMS Microbiol Ecol. 2008;63:169.

13. Berg G, Köberl M, Rybakova D, Müller H, Grosch R, Smalla K. Plant microbial diversity is suggested as the key to future biocontrol and health trends. FEMS Microbiol Ecol. 2017; https://doi.org/10.1093/femsec/fix050.

14. Luo S, Wan Y, Xiao X, Guo HJ, Chen L, Xi Q, Zeng GM, Liu CB, Chen JL. Isolation and characterization of endophytic bacterium LRE07 from cadmium hyperaccumulator Solanum nigrum L. and its potential for remediation. Appl Microbiol Biotechnol. 2011;89:1637-4.

15. Silver S, Phung LT. Genes and enzymes involved in bacterial oxidation and reduction of inorganic arsenic. Appl Environ Microbiol. 2005;71:599-608.

16. Bhattacharjee $H$, Rosen BP. Arsenic metabolism in prokaryotic and eukaryotic microbes. Mol Microbiol Heavy Metals. 2007;6:371-6.

17. Achour AR, Bauda P, Billard P. Diversity of arsenite transporter genes from arsenic-resistant soil bacteria. Res Microbiol. 2007;158:128-7.

18. Chen HL, Zhang SR, Li T, Dai Y, Mao Z. Heavy- metal accumulation and tolerance of plants at zinc- lead mine tailings in Hanyuan. J Agro-Environ Sci. 2007;26:505-9. (In Chinese)

19. Gallego JR, Esquinas N, Rodríguez-Valdés E, Menéndez-Aguado JM, Sierra C. Comprehensive waste characterization and organic pollution co-occurrence in a hg and as mining and metallurgy brownfield. J Hazard Mater. 2015;300:561-1.

20. Lu RK. Soil and agro-chemical analytical methods. Beijing, China: China Agricultural Science and Technology Press; 1999. p. 146-95. (in Chinese)

21. Chang SS, Hsu HL, Cheng JC, Tseng CP. An efficient strategy for broadrange detection of low abundance bacteria without DNA decontamination of PCR reagents. PLoS One. 2011;6:e20303.

22. Wilmotte A, Van Der Auwera G, De Wachter R. Structure of the 165 ribosomal RNA of the thermophilic cyanobacterium Chlorogloeopsis HTF ('Mastigocladus laminosus HTF') strain PCC7518, and phylogenetic analysis. FEBS Lett. 1993;317:96

23. Larkin MA, Blackshields G, Brown NP, Chenna R, McGettigan PA, McWilliam H, Valentin F, Wallace IM, Wilm A, Lopez R, Thompson JD, Gibson TJ, Higgins DG. ClustalW2 and ClustalX version 2. Bioinformatics. 2007;23:2947-8.

24. Tamura K, Peterson D, Peterson N, Stecher G, Nei M, Kumar S. MEGA 5: molecular evolutionary genetics analysis using maximum-likelihood, evolutionary distance, and maximum parsimony methods. Mol Biol Evol. 2011;28:2731-9.

25. Sheng XF, Xia JJ, Jiang CY, He LY, Qian M. Characterization of heavy metalresistant endophytic bacteria from rape (Brassica napus) root and their potential in promoting the growth and lead accumulation of rape. Environ Pollut. 2008;156:1164

26. Schwyn B, Neilands JB. Universal chemical assay for the detection and determination of siderophores. Anal Biochem. 1987;160:47-6.

27. Manjanatha MG, Loynachan TE, Atherly AG. Tn5 mutagenesis of Chinese Rhizobium fredii for siderophore over production. Soil Biol Biochem. 1992;24:151-5.

28. Khan MU, Sessitsch A, Harris M, Fatima K, Imran A, Arslan M, Shabir G, Khan QM, Afzal M. Cr-resistant rhizo- and endophytic bacteria associated with Prosopis juliflora and their potential as phytoremediation enhancing agents in metal-degraded soils. Front Plant Sci. 2015;5:755.

29. Chang JS, Yoon IH, Kim KW. Isolation and ars detoxification of arseniteoxidizing bacteria from abandoned arsenic-contaminated mines. J Microbiol Biotechnol. 2007;17:812-1.

30. Corsini A, Cavalca L, Zaccheo P, Crippa L, Andreoni V. Influence of microorganisms on arsenic mobilization and speciation in a submerged contaminated soil: effects of citrate. Appl Soil Ecol. 2011;49:99-6.

31. Cordi A, Pagnout C, Devin S, Poirel J, Billard P, Dollard MA, Bauda P. Determination of physiological, taxonomic, and molecular characteristics of a cultivable arsenic-resistant bacterial community. Environ Sci Pollut Res Int. 2015;22:13753-3.

32. Qamar N, Rehman Y, Hasnain S. Arsenic-resistant and plant growthpromoting Firmicutes and $\gamma$-Proteobacteria species from industrially polluted irrigation water and corresponding cropland. J Appl Microbiol. 2017;123:748-8.

33. Barzanti R, Ozino F, Bazzicalupo M, Gabbrielli R, Galardi F, Gonnelli C, Mengoni A. Isolation and characterization of endophytic bacteria from the nickel hyperaccumulator plant Alyssum bertolonii. Microb Ecol. 2007:53:306-6.
34. Long XX, Chen XM, Chen YG, Woon-Chung WJ, Wei ZB, Wu QT. Isolation and characterization endophytic bacteria from hyperaccumulator Sedum alfredii Hance and their potential to promote phytoextraction of zinc polluted soil. World J Microbiol Biotechnol. 2011;27:1197-7.

35. Zhu LJ, Guan DX, Luo J, Rathinasabapathi B, Ma LQ. Characterization of arsenic-resistant endophytic bacteria from hyperaccumulators Pteris vittata and Pteris multifida. Chemosphere. 2014;113:9-6.

36. Fierer N, Lauber CL, Ramirez KS, Zaneveld J, Bradford MA, Knight R. Comparative metagenomic, phylogenetic and physiological analyses of soil microbial communities across nitrogen gradients. ISME J. 2012;6:1007-7.

37. Ali S, Duan J, Charles TC, Glick BR. A bioinformatics approach to the determination of genes involved in endophytic behavior in Burkholderia spp. J Theor Biol. 2014;343:193-8.

38. Tiwari S, Sarangi BK, Thul ST. Identification of arsenic resistant endophytic bacteria from Pteris vittata root and characterization for arsenic remediation application. J Environ Manag. 2016;180:359-65.

39. Taghavi S, Barac T, Greenberg B, Borremans B, Vangronsveld J, van der Lelie D. Horizontal gene transfer to endogenous endophytic bacteria from poplar improves phytoremediation of toluene. Appl Environ Microbiol. 2005;71: 8500-5.

40. Rajkumar M, Ae N, Prasad MNV, Freitas H. Potential of siderophoreproducing bacteria for improving heavy metal phytoextraction. Trends Microbiol. 2010;28:142-9.

41. Schalk IJ, Hannauer M, Braud A. New roles for bacterial siderophores in metal transport and tolerance. Environ Microbiol. 2011;13:2844-4.

42. Jackson CR, Harrison KG, Dugas SL. Enumeration and characterization of culturable arsenate resistant bacteria in a large estuary. Syst Appl Microbiol. 2005;28:727-4.

43. Huang A, Teplitski M, Rathinasabapathi B, Ma L. Characterization of arsenicresistant bacteria from the rhizosphere of arsenic hyperaccumulator Pteris vittata. Can J Microbiol. 2010;56:236-46.

44. Cai L, Liu GH, Rensing C, Wang GJ. Genes involved in arsenic transformation and resistance associated with different levels of arsenic-contaminated soils. BMC Microbiol. 2009;9:4

45. Maizel D, Blum JS, Ferrero MA, Utturkar SM, Brown SD, Rosen BP, Oremland RS. Characterization of the extremely arsenic-resistant Brevibacterium linens strain AE038-8 isolated from contaminated groundwater in Tucumán, Argentina. Int Biodeterior Biodegrad. 2016;107:147-3.

46. Arsène-Ploetze F, Koechler S, Marchal M, Coppée JY, Chandler M, Bonnefoy V, Brochier-Armanet C, Barakat M, Barbe V, Battaglia-Brunet F, Bruneel O, Bryan CG, Cleiss-Arnold J, Cruveiller S, Erhardt M, Heinrich-Salmeron A, Hommais F, Joulian C, Krin E, Lieutaud A, Lièvremont D, Michel C, Muller D, Ortet $P$, Proux C, Siguier P, Roche D, Rouy Z, Salvignol G, Slyemi D, Talla E, Weiss S, Weissenbach J, Médigue C, Bertin PN. Structure, function, and evolution of the Thiomonas spp. Genome PLoS Genet. 2010;6:e1000859.

47. Zhao CG, Zhang Y, Chan ZH, Chen SC, Yang SP. Insights into arsenic multioperons expression and resistance mechanisms in Rhodopseudomonas palustris CGA009. Front Microbiol. 2015:6:986.

48. Cavalca L, Zanchi R, Corsini A, Colombo M, Romagnoli C, Canzi E, Andreoni V. Arsenic-resistance bacteria associated with roots of the wild Cirsium arvense (L.) plant from an arsenic polluted soil, and screening of potential plant growth-promoting characteristics. Syst Appl Microbiol. 2010;33:154-64.

49. Jackson CR, Dugas SL. Phylogenetic analysis of bacterial and archaeal arsC gene sequences suggests an ancient, common origin for arsenate reductase. BMC Evol Biol. 2003:3:18

50. Richard D, Ravigné V, Rieux A, Facon B, Boyer C, Boyer K, Grygiel P, Javegny $\mathrm{S}$, Terville M, Canteros BI, Robènel VC, Chabirand A, Pruvost O, Lefeuvre P. Adaptation of genetically monomorphic bacteria: evolution of copper resistance through multiple horizontal gene transfers of complex and versatile mobile genetic elements. Mol Ecol. 2017;26:2131-9. 